\title{
Performance in the Deep Squat Test and musculoskeletal injuries: a systematic review
}

\author{
O desempenho no Teste de Agachamento Profundo e \\ lesões musculoesqueléticas: uma revisão sistemática
}

\author{
Priscila dos Santos Bunn ${ }^{[a, b]}$, Glória de Paula Silva ${ }^{[a]}, E$ Elirez Bezerra da Silva ${ }^{[a]^{*}}$
}

[a] Universidade do Estado do Rio de Janeiro (UERJ), Rio de Janeiro, RJ, Brazil

[b] Centro de Educação Física Almirante Adalberto Nunes (CEFAN) - Marinha do Brasil, Rio de Janeiro, RJ, Brazil

\begin{abstract}
Introduction: The Deep Squat Test has been applied in pre-season evaluations of sports teams and in military courses to predict the risk of musculoskeletal injuries. Objective: To evaluate the association of DS performance and the risk of musculoskeletal injuries. Methods: In this systematic review, a search without language or time filters was carried out in MEDLINE, SciELO, SCOPUS, SPORTDiscuss, CINAHL and BVS databases with the following title words: injury prediction, injury risk and deep squat in December 2016. Participants' profile, sample size, classification of musculoskeletal injuries, follow-up time, study design and results were extracted from the studies. Bias risk analysis was performed with the Newcastle-Ottawa Scale. Results: Five studies were included, using different analyzes, whose results varied. Odds ratio ranged from 1.21 to $2.59(95 \% \mathrm{CI}=1.01-3.28)$; relative risk was $1.68(95 \% \mathrm{CI}=1.50-1.87)$, sensitivity from 3 to $24 \%$, specificity from 90 to $99 \%$, PPV from 42 to $63 \%$, NPV from 72 to $75 \%$ and AUC from 51 to $58 \%$. Conclusion: The DS can be a test whose presence of movement dysfunctions is a predictor of the risk of musculoskeletal injuries in individuals who practice physical exercises. However, due to the methodological limitations presented, caution is suggested when interpreting such results. PROSPERO registration: CRD4201706922.
\end{abstract}

Keywords: Movement. Athletic Injuries. Screening.

\footnotetext{
* PSB: Doctoral student, e-mail: priscilabunn@yahoo.com.br GPS: Master's student, e-mail: gloriaps_ibnj@hotmail.com EBS: PhD, e-mail: elirezsilva@cosmevelho.com.br
} 


\section{Resumo}

Introdução: O Teste de Agachamento Profundo (TAP) tem sido utilizado em avaliações pré-temporada de equipes esportivas e em cursos militares para classificar o risco de lesões musculoesqueléticas. Objetivo: Avaliar a associação do desempenho no TAP e o risco de lesões musculoesqueléticas. Métodos: Nesta revisão sistemática, uma pesquisa sem filtros de linguagem ou de tempo foi realizada nas bases de dados MEDLINE, SciELO, SCOPUS, SPORTDdiscusS, CINAHL e BVS com as seguintes palavras-título: predição de lesões, risco de lesão e agachamento profundo em dezembro de 2016. Perfil dos participantes, tamanho da amostra, classificação das lesões musculoesqueléticas, tempo de seguimento, desenho do estudo e os resultados foram extraídos dos estudos. A análise do risco de viés foi realizada com a Escala Newcastle-Ottawa. Resultados: Foram incluídos cinco estudos, utilizando diferentes análises, cujos resultados variaram. $O$ odds ratio variou de 1,21 a 2,59 (IC 95\% = 1,01-3,28); 0 risco relativo foi de 1,68 (IC 95\% = 1,50 - 1,87), sensibilidade de 3 a 24\%, especificidade de 90 a 99\%, VPP de 42 a 63\%, VPN de 72 a 75\% e AUC de 51 a 58\%. Conclusão: O TAP pode ser um teste cuja presença de disfunções de movimento é um preditor do risco de lesões musculoesqueléticas em indivíduos que praticam exercícios físicos. No entanto, devido às limitações metodológicas apresentadas, sugere-se cautela ao interpretar esses resultados. Registro PROSPERO: CRD4201706922.

Palavras-chave: Movimento. Lesões Atléticas. Triagem.

\section{Introduction}

Deep Squat Test (DS) is one of tests of the Functional Movement Screen ${ }^{\mathrm{TM}}\left(\mathrm{FMS}^{\mathrm{TM}}\right)$ [1] and Dynamic Movement Assessment $^{\mathrm{TM}}\left(\mathrm{DMA}^{\mathrm{TM}}\right)$ [2], tools to classify the risk of musculoskeletal injuries. DS has been applied in preseason evaluations of sports teams [3 -5] and in military courses [6]. It is considered the test that predict the risk score at FMS ${ }^{\text {TM }}$ [3]. At the same time, DS is an exercise to increase muscular strength, stability, trunk control and sports performance in several modalities, as it allows the recruitment of various muscle groups in a single repetition [7]. It is a low-cost, and easy-to-perform test in various places.

During the DS, squatting is performed with angles greater than 90 degrees of hip flexion. The performance in DS is influenced by several factors, such as the mobility of the lumbar spine, hip, knee and ankle joints, as well as the movement pattern $[2,8,9]$.

The parameters that can be evaluated in DS are the presence of lateral deviation of the pelvis, range of motion, excessive trunk flexion, elevation of the heels in relation to the ground, hip adduction and equilibrium losses $[2,7,10]$. Lateral deviation of the pelvis is considered the most serious deviation, as it promotes imbalance of strength and flexibility between the sides, and may result from a limitation of the range of motion, proprioception deficit, pain, quadriceps strength or motor control $[11,12]$. Limitation of movement in DS may be due to pain or reduced mobility of the hip, knee, lumbar spine, or ankle [2,13 - 15]. The increase in trunk flexion promotes a change in loads on the lumbar spine, overloading it, as well as impacting on strength and muscle power of trunk and lower limbs related to training [7, 9]. Elevation of the heel from the ground can reduce the range of motion during squatting as a consequence of the lack of extensibility of the plantiflexers or of a foot or ankle hypomobility $[9,16]$. Hip adduction and / or internal rotation of femur negatively impacts the generation of strength and muscular power in athletes, and is visualized when the medial side of the patella on one or both sides move medially due to lack of core stability, proprioceptive deficit and strength of hip abductors and ankle hypomobility $[9,16]$. The loss of balance when performing DS may be associated with poor core stability, and an important joint limitation $[11,12,17]$.

Studies evaluated the association of FMS ${ }^{\mathrm{TM}}$ risk score in the development of musculoskeletal injuries $[18,19]$, however, the isolated effect of the DS is uncertain, since there are no revisions on the subject. Therefore, the objective of this systematic review was to evaluate if there is association of the DS with musculoskeletal injuries in individuals who practice physical exercises.

\section{Method}

This systematic review was drafted based on the PRISMA [20] and Leeflang [21] recommendations 
and registered in the International prospective register of systematic reviews with the number CRD4201706922.

\section{Inclusion criteria}

Were included prospective studies of DS as a risk classification test for musculoskeletal injuries during the practice of physical exercises, with full text available, and DS may have been performed as an integral part of assessment methods, since it has been performed an isolated analysis of their performance with injuries risk, and without language filter.

\section{Search strategy}

A search was made in December 2016 in the databases National Library of Medicine (MEDLINE), Scientific Electronic Library Online (SciELO), SCOPUS, SPORTDiscuss, The Cumulative Index to Nursing and Allied Health Literature (CINAHL) and Virtual Health Library (BVS). The following keywords were used as descriptors of the Medical Subject Headings (MeSH): injury prediction, injury risk and deep squat. The search phrase was obtained using the logic operators AND (between the descriptors) and OR (between the synonyms). There was no language filter or delimitation of a period for the search.

\section{Data collection process}

The following data were extracted from the selected studies: the profile of the participants, sample size, definition of musculoskeletal injuries, follow-up time, study design and results presented according to the study design used, with their respective levels of significance.

Bias risk analysis

For bias risk analysis, stars were awarded to the items of the Newcastle-Ottawa quality assessment scale at study level $[22,23]$, that consists of three domains: 1) selection (representativeness of the exposed cohort, selection of the unexposed cohort, ascertainment of exposure, demonstration that outcome of interest was not present at start of study);2) comparability of the cohorts on the basis of design or analysis (pairing of main variables and other confounding variables); and 3) outcome (assessment of outcome, follow-up time to the outcome occurs, adequacy of follow-up of cohort). For each criterion served in the domains, a star is provided. Studies with a total of five stars or more are classified with "low risk" of bias. If the study does not receive any star in the "comparability" domain, the study will be classified as "uncertain risk". Studies with four stars or less have a "high risk" of bias.

\section{Results}

The total number of studies per database, the recovery flow of the studies that analyzed the association of DS with the risk of musculoskeletal injuries and the reasons for excluding studies are shown in Figure 1. Five studies [24 - 28] evaluated the association of DS with the risk of musculoskeletal injuries. Characteristics of the included studies are in the Table 1 and the results of the statistical analysis of the studies are in Table 2 . The bias risk analysis performed in the five studies selected from DS are in the Table 3.

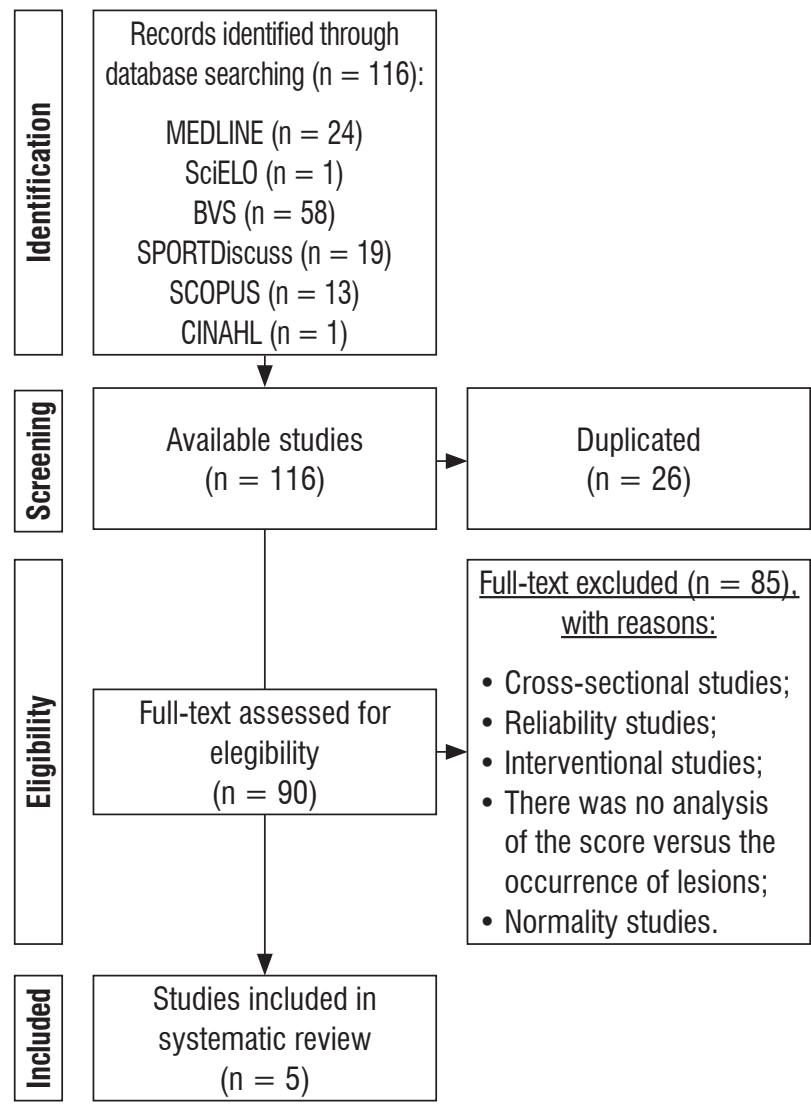

Figure 1 - Flow diagram of the included studies. 
Table 1 - Characteristics of the studies included.

\begin{tabular}{|c|c|c|c|}
\hline Study & Sample characteristics & Injury definition & Follow-up time \\
\hline Butler et al., 2013 [25] & $\begin{array}{l}n=108 \text { firefighter students } \\
\text { Age }=N R\end{array}$ & $\begin{array}{l}\text { More than } 3 \text { days away from functions due to } \\
\text { musculoskeletal pain }\end{array}$ & 4 months \\
\hline Bushman et al., 2015 [26] & $\begin{array}{l}n=2476 \text { soldiers } \\
\text { Age }=18-57 \text { years old }\end{array}$ & Simple record of traumatic and non-traumatic injuries & 6 months \\
\hline Hotta et al., 2015 [27] & $\begin{array}{l}n=84 \text { male runners. } \\
\text { Age }=18-24 \text { years old }\end{array}$ & $\begin{array}{l}\text { Two prerequisites were used: (1) The injury occurred as a } \\
\text { result of participating in race or training events (traumatic } \\
\text { injuries were excluded); (2) the injury was severe enough } \\
\text { to prevent athletic activities for at least } 4 \text { weeks }\end{array}$ & 6 months \\
\hline Zalai et al., 2015 [28] & $\begin{array}{l}n=20 \text { football players } \\
\text { Age }=23 \pm 1 \text { years old }\end{array}$ & $\begin{array}{l}\text { Injury that caused the athlete to be separated from his / her } \\
\text { activities, according to the criterion: minimum (1-7 days); } \\
\text { Moderate (8-28 days) and severe (> } 28 \text { days), according } \\
\text { to Hägglund et al., (2005) [30]. }\end{array}$ & 6 months \\
\hline Tee et al., 2016 [29] & $\begin{array}{l}n=62 \text { rugby players } \\
\text { Age }=N R\end{array}$ & $\begin{array}{l}\text { Considered only the serious injuries (time loss greater than } \\
28 \text { days), which were subdivided into contact injuries, } \\
\text { non-contact injuries, or any injury (Fuller et al., 2006) [31]. }\end{array}$ & 6 months \\
\hline
\end{tabular}

Note: $\mathrm{NR}=$ Not reported; $\mathrm{n}=$ sample size.

Table 2 - Statistical Analysis of the included studies.

\begin{tabular}{|c|c|c|}
\hline Statistical analysis & Author & Results \\
\hline Odds ratios & $\begin{array}{l}\text { Butler et al., } 2013 \text { [25] } \\
\text { Bushman et al., } 2015 \text { [24] }\end{array}$ & $\begin{array}{l}\text { OR: } 1.21(\mathrm{Cl} 95 \%=1.01-1.42) \\
\mathrm{OR}=2.59(\mathrm{Cl} 95 \%=2.05-3.28) ; \mathrm{P}<0.01\end{array}$ \\
\hline Diagnostic accuracy & Bushman et al., 2015 [24] & $\begin{array}{l}s=3-24 \% \\
e=90-99 \% \\
P P V=57(42-63 \%) ; N P V=66(72-75 \%) ; A U C=51-58 \%\end{array}$ \\
\hline Relative risk & Bushman et al., 2015 [24] & $\mathrm{RR}^{*}=1.68(\mathrm{Cl} 95 \%=1.50-1.87)$ \\
\hline Mann-Whitney Test. & Hotta et al., 2015 [26] & $\begin{array}{l}\text { IG: } 1.8 \pm 0.7 \\
\text { NIG: } 1.3 \pm 0.7 \text { com } P<0.01\end{array}$ \\
\hline Pearson's correlate coefficient. & Zalai et al., 2015 [28] & $\begin{array}{l}\text { Statistical power }=0.56 \\
I G=1.67 \pm 0.51 ; \mathrm{NIG}=2.21 \pm 0.42 \\
P<0.05\end{array}$ \\
\hline ES (Cohen) & Tee et al., 2016 [30] & $\begin{array}{l}\mathrm{ES}=0.60 \text { (IG versus NIG); } \\
\mathrm{ES}(\mathrm{TI})=1.04 \text { (large) } \\
\mathrm{ES}(\mathrm{NTI})=0.20 \text { (small) }\end{array}$ \\
\hline
\end{tabular}

Note: $\mathrm{NR}=$ Not reported; $\mathrm{OR}=$ Odds Ratios; $\mathrm{Cl}$ 95\% = confidence interval to 95\%; $\mathrm{s}=$ sensitivity; e = specificity; PPV = positive predictive value; NPV = negative predictive value; $A U C=$ area under the curve "receiver operator characteristic"; IG = injured group; NIG = non-injured group; $\mathrm{TI}=$ traumatic injuries; NTI = non-traumatic injuries; $\mathrm{ES}=$ effect size; RR = relative risk; * $=$ RR not available, but calculated in the present review by Table $2 \times 2$ of the study.

Table 3 - Risk of bias (NOS Cohort)

\begin{tabular}{|c|c|c|c|c|c|}
\hline \multirow[t]{2}{*}{ Authors } & \multicolumn{3}{|c|}{ Domains } & \multicolumn{2}{|c|}{ Results } \\
\hline & Selection & Comparability & Outcome & Score & Risk \\
\hline Butler et al., 2013 [25] & $\star \star \star \star *$ & - & ** & 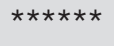 & Uncertain \\
\hline Bushman et al., 2015 [24] & $\star * *$ & ** & * & 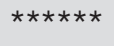 & Low \\
\hline Hotta et al., 2015 [26] & $\star \star \star *$ & - & * & $\star \star \star \star *$ & High \\
\hline Zalai et al., 2015 [28] & $\star \star \star$ & - & * & $\star * \star *$ & High \\
\hline Tee et al., 2016 [30] & $\star \star \star *$ & - & * & $* \star \star *$ & High \\
\hline
\end{tabular}

Note: Domains of Newcastle-Ottawa Scale (NOS) [22, 23]: Selection (representativeness of the exposed cohort; selection of the non-exposed cohort; ascertainment of exposure and demonstration that outcome of interest was not present at start of study); Comparability (principal factor and any additional factor); and Outcome (assessment of outcome; if the follow-up was long enough for outcomes to outcome occurs; and adequacy of follow-up of cohorts). 


\section{Discussion}

Of the five selected studies, one utilized indicators of diagnostic accuracy (24). According to Bushman et al [24]., DS has low sensitivity (3 - 24\%), high specificity ( 90 - 99\%), PPV $=42-63 \%$; NPV $=72-75 \%$ and AUC $=51-58$, indicating that the level of accuracy of the test is discreetly above chance [32]. On the other hand, Tee et al. [27] concluded that the effect size (ES) when performing DS as a predictor of non-contact injuries was small ( $E S=0.20)$, mean for all injuries (ES $=0.6$ ) and large for contact injuries $(E S=1.04)$ [33]. The divergence among the results of such studies is possibly due to the use of different samples and the analysis of indicators of diagnostic accuracy $[34,35]$. Moreover, effect size may not have been the most indicated analysis for the risk of injury associated with a low DS score [33, 36].

Due to the prospective nature, the most appropriate for the studies would be to analyze the results by relative risk (RR). In this way, it would be possible to relate the incidence of injury between the injured and non-injured groups [37]. None of the authors performed the RR calculation. Only the study by Bushman et al., [24] provided a 2 x 2 table, which made it possible to calculate the RR in the present review, whose value was 1.68 (95\% $\mathrm{CI}=1.50$ - 1.87). This result is significant, since the lower limit of the confidence interval is 0.50 over chance and increases the risk of injury by 0.68 , respectively, showing an association of the low DS score with the risk of injury. The studies of Butler et al. [25], Hotta et al. [26], Zalai et al. [28], and Tee et al. [27] utilized comparisons of means between the groups and odds ratio in their analyzes, which were inadequate for the adopted cohort design. For this reason, these studies contributed little to the conclusion of this review.

Classification of injuries in studies of prediction of musculoskeletal injuries is one of the main challenges of the authors. According with Hägglund et al. [29], an injury is defined when three criteria are met: (1) the injury affects the musculoskeletal system in a traumatic or overuse way, being diagnosed by a medical professional; (2) arises from athletic participation; and (3) time loss his or her sporting tasks for at least 24 hours. In the present review, it is verified that only one study meets the three criteria [28], being the classification divergent and incomparable among the authors. The follow-up time should be long enough to allow observation of the injuries, and was similar among the authors, ranging from four to six months.

The bias risk analysis showed that, in relation to the "selection" domain, the studies presented at least three stars of four possible. Only one study scored in the "comparability" domain between the groups exposed and not exposed to the risk factor [24]. The worst bias scores occurred in the "outcome" domain (Table 3). None of the studies specified whether blinding occurred between DS execution by the participants and the incidence of injury in both groups afterwards. Moreover, there is not a description of attrition rate and reasons. The studies of Bushman et al. [24] and Butler et al. [25] showed the lowest risk of bias, with a score of six stars. However, the study of Butler et al. [25] did not report the existence of pairing. Consequently, was attributed an uncertain risk of bias for this study. Blinding and pairing of potential confounders (age, gender, and other risk factors) could minimize such risks of bias $[22,38]$.

A major limitation of this review is the limited amount of studies included. However, the search was as the most comprehensive as possible, but there is a limited number of published articles on this subject, although DS is a widely-practiced test in sports practice. At the same time, despite the five studies included, the conclusion of this review was based only on one study, that of Bushman et al. [24], because it was the only one that analyzed the relative risk, an appropriate measure of effect to associate the presence of a factor with the incidence of an injury.

As a strong point, this was the first review that evaluated DS's ability as a predictor of injury. The use of a specific bias risk assessment scale for cohort studies has enabled the development of suggestions for future DS cohort studies or other functional tests as predictive tests of injuries. Finally, the most appropriate analysis was identified for cohort studies that sought to associate functional tests with the risk of injury: relative risk [38 - 40].

Probably, the presence of movement dysfunctions in the DS is a predictor of the musculoskeletal injuries in individuals who practice physical exercises. This initial conclusion is based on a single study, the study by Bushman et al. [24], which presented the fewer risk of bias and assessed the relative risk, an appropriate measure of effect for cohort studies. 
Due to its easy implementation and low cost, DS can be used in conjunction with other assessment methods, especially in sports pre-seasons. Considering this and the methodological limitations presented in this review, it is suggested to carry out cohort studies with more representative samples, matching sex, age and other confounding variables and with blinding between the stages of motor dysfunction evaluation with DS and the diagnosis of injury.

\section{References}

1. Cook G, Burton L, Hoogenboom B. Pre-participation screening: the use of fundamental movements as an assessment of function - Part 1. N Am J Sports Phys Ther. 2006;1(2):62-72.

2. Kiesel KB, Butler RJ, Plisky PJ. Prediction of injury by limited and asymmetrical fundamental movement patterns in american football players. J Sport Rehabil. 2014;23(2):88-94.

3. Nessler T, Dunn EH. Dynamic Movement Assessment: Prevent Injury and Enhance Performance. Fribourg, CH: Publiwide; 2014.

4. Clifton DR, Grooms DR, Onate JA. Overhead Deep Squat Performance Predicts Functional Movement ScreenTM Score. Int J Sports Phys Ther. 2015;10(5):622-7.

5. McCall A, Davison M, Andersen TE, Beasley I, Bizzini $\mathrm{M}$, Dupont $\mathrm{G}$, et al. Injury prevention strategies at the FIFA 2014 World Cup: perceptions and practices of the physicians from the 32 participating national teams. Br J Sports Med. 2015;49(9):603-8.

6. Snoeker BAM, Lindeboom R, Zwinderman AH, Vincken PWJ, Jansen JA, Lucas C. Detecting Meniscal Tears in Primary Care: Reproducibility and Accuracy of 2 Weight-Bearing and 1 Non-Weight-Bearing Tests. J Orthop Sports Phys Ther. 2015;45(9):693-702.

7. Crossley KM, Zhang WJ, Schache AG, Bryant A, Cowan SM. Performance on the single-leg squat task indicates hip abductor muscle function. Am J Sports Med. 2011;39(4):866-73.

8. Schoenfeld BJ. Squatting kinematics and kinetics and their application to exercise performance. J Strength Cond Res. 2010;24(12):3497-506.
9. Mauntel TC, Post EG, Padua DA, Bell DR. Sex Differences During an Overhead Squat Assessment. J Appl Biomech. 2015;31(4):244-9.

10. Kim SH, Kwon OY, Park KN, Jeon IC, Weon JH. Lower extremity strength and the range of motion in relation to squat depth. J Hum Kinet. 2015;45:59-69.

11. Kiesel K, Plisky PJ, Voight ML. Can serious injury in professional football be predicted by a preseason functional movement screen? N Am J Sports Phys Ther. 2007;2(3):147-58.

12. Atkins SJ, Bentley I, Hurst HT, Sinclair JK, Hesketh C. The Presence of Bilateral Imbalance of the Lower Limbs in Elite Youth Soccer Players of Different Ages. J Strength Cond Res. 2016;30(4):1007-13.

13. Newton RU, Gerber A, Nimphius S, Shim JK, Doan BK, Robertson $\mathrm{M}$, et al. Determination of functional strength imbalance of the lower extremities. J Strength Cond Res. 2006;20(4):971-7.

14. Lamontagne M, Kennedy MJ, Beaulé PE. The effect of cam FAI on hip and pelvic motion during maximum squat. Clin Orthop Relat Res. 2009;467(3):645-50.

15. Weeks BK, Carty CP, Horan SA. Effect of sex and fatigue on single leg squat kinematics in healthy young adults. BMC Musculoskelet Disord. $2015 ; 16: 271$.

16. Graci V, Van Dillen LR, Salsich GB. Gender differences in trunk, pelvis and lower limb kinematics during a single leg squat. Gait Posture. 2013;36(3):461-6.

17. Lee JD, Koh DH, Kim K. The kinematics of the lower leg in the sagittal plane during downward squatting in persons with pronated feet. J Phys Ther Sci. 2015;27(1):285-7.

18. Shirey M, Hurlbutt M, Johansen N, King GW, Wilkinson SG, Hoover DL. The influence of core musculature engagement on hip and knee kinematics in women during a single leg squat. Int J Sports Phys Ther . 2012;7(1):1-12.

19. Dorrel BS, Long T, Shaffer S, Myer GD. Evaluation of the Functional Movement Screen as an Injury Prediction Tool Among Active Adult Populations: A Systematic Review and Metaanalysis. Sports Health. 2015;7(6):532-7. 
20. McCunn R, Aus der Fünten K, Fullagar HH, McKeown I, Meyer T. Reliability and Association with Injury of Movement Screens: A Critical Review. Sports Med. 2016;46(6):763-81.

21. Moher D, Liberati A, Tetzlaff J, Altman DG; PRISMA Group. P Preferred reporting items for systematic reviews and meta-analyses: the PRISMA statement. Ann Intern Med. 2009;151(4):264-9, W64.

22. Leeflang MM, Deeks JJ, Gatsonis C, Bossuyt PM. Systematic reviews of diagnostic test accuracy. Ann Intern Med. 2008;149(12):889-97.

23. Wells GA, Shea B, O'Connell D, Peterson J, Welch V, Losos M, et al. The Newcastle-Ottawa Scale ( NOS ) for assessing the quality of nonrandomised studies in meta- analyses. [cited 2017 Oct 16]. Available from: https://tinyurl.com/y76gsbrx

24. Margulis AV, Pladevall M, Riera-Guardia N, VarasLorenzo C, Hazell L, Berkman ND, et al. Quality assessment of observational studies in a drugsafety systematic review, comparison of two tools: the Newcastle-Ottawa Scale and the RTI item bank. Clin Epidemiol. 2014;6:359-68.

25. Butler RJ, Contreras M, Burton LC, Plisky PJ, Goode A, Kiesel K. Modifiable risk factors predict injuries in firefighters during training academies. Work. 2013;46(1):11-7.

26. Bushman TT, Grier TL, Canham-Chervak MC, Anderson MK, North WJ, Jones BH. Pain on Functional Movement Screen Tests and Injury Risk. J Strength Cond Res. 2015;29(Suppl 11):S65-70.

27. Hotta T, Nishiguchi S, Fukutani N, Tashiro Y, Adachi D, Morino S, et al. Functional Movement Screen for Predicting Running Injuries in 18- to 24-Year-Old Competitive Male Runners. J Strength Cond Res. 2015;29(10):2808-15.

28. Zalai D, Panics G, Bobak P, Csáki I, Hamar P. Quality of functional movement patterns and injury examination in elite-level male professional football players. Acta Physiol Hung. 2015;102(1):34-42.

29. Tee JC, Klingbiel JF, Collins R, Lambert MI, Coopoo Y. Preseason Functional Movement Screen component tests predict severe contact injuries in professional rugby union players. J Strength Cond Res. 2016;30(11):3194-203.
30. Hägglund M, Waldén M, Bahr R, Ekstrand J. Methods for epidemiological study of injuries to professional football players: developing the UEFA model. Br J Sports Med. 2005;39(6):340-6.

31. Fuller CW, Molloy MG, Bagate C, Bahr R, Brooks JH, Donson $\mathrm{H}$, et al. Consensus statement on injury definitions and data collection procedures for studies of injuries in rugby union. Br J Sports Med. 2007;41(5):328-31.

32. Hajian-Tilaki K. Receiver Operating Characteristic (ROC) Curve Analysis for Medical Diagnostic Test Evaluation. Caspian J Intern Med. 2013;4(2):627-35.

33. Chen H, Cohen P, Chen S. How Big is a Big Odds Ratio? Interpreting the Magnitudes of Odds Ratios in Epidemiological Studies. Commun Stat Simul Comput. 2010;39(4):860-4.

34. Bossuyt PM, Reitsma JB, Bruns DE, Gatsonis CA, Glasziou PP, Irwig LM, et al. The STARD statement for reporting studies of diagnostic accuracy: explanation and elaboration. Ann Intern Med. 2003;138(1):W1-12.

35. Oliveira MRF, Gomes AC, Toscano CM. QUADAS and STARD: evaluating the quality of diagnostic accuracy studies. Rev Saude Publica. 2011;45(2):416-22.

36. Rumel D. "Odds ratio": algumas considerações. Rev Saude Publica. 1986;20(3):253-8.

37. Oliveira MAP, Parente RCM. Estudos de Coorte e de Caso-Controle na Era da Medicina Baseada em Evidência. Braz J Vide-Sur. 2010;3(3):115-25.

38. McNutt LA, Wu C, Xue X, Hafner JP. Estimating the relative risk in cohort studies and clinical trials of common outcomes. Am J Epidemiol. 2003;157(10):940-3.

39. Yada Y. Method to estimate relative risk using exposed proportion and case group data. Sci Rep. 2017;7:2131.

40. Colditz GA. Overview of the epidemiology methods and applications: strengths and limitations of observational study designs. Crit Rev food Sci Nutr. 2010;50(Suppl 1):10-2.

Received in 07/19/2017

Recebido em 19/07/2017

Approved in 10/06/2017 Aprovado em 06/10/2017 